\title{
COMMUNICATION OF ART VIA OPEN RESEARCH: ON CULTURAL POLICIES, HERITAGE AND RECEPTION OF INNOVATION IN ART
}

\author{
Pedro Andrade
}

\begin{abstract}
This article debates some main modes of art communication within the urban public space, and their interpretation through Open Research. In particular, it discusses communication regimes in places where cultural and artistic events occur, such as the museum. One of the communicative phenomena circulating there is informal art literacy, which is a different and sometimes opposite process in relation to the formal education at school. Having this aim in mind, firstly two core concepts within Art Communication Studies, which are crucial to this debate, are defined: Public Communication of Art-PCA and art literacy. Secondly, questions pertaining to art communication are raised: the definition of cultural policies that allow cultural inclusion of diverse art publics segments; the role of digital devices to improve the understanding of cultural heritage; the more adequate communication and management strategies for improving publics literacy; the reception process undertaken by cultural audiences around art ideas and concepts shared through art events. Thirdly, such questions are framed within the main theoretical and authors' positioning in Art Communication Studies. Next, some brief practical advices and recommendations concerning how to develop a research on communication within art worlds are exposed in two parts: the first part suggests some hypothesis corresponding to the previous formulated questions. The second part establishes a synthetic and practical agenda for doing a research on this subject. Some emergent sociological apparatuses, produced to improve the social and cultural impact of art communication, are also presented. Finally, specific modes and targets of this impact are discussed.
\end{abstract}

\section{Keywords}

Art communication studies; art literacy; art reception; intermedia sociologic methodology; public communication of art

\section{Resumo}

Este artigo debate alguns dos principais modos de comunicação da arte subjacentes ao espaço público urbano, e a sua interpretação através da Investigação Aberta. Em particular, discute os regimes de comunicação presentes em locais onde ocorrem eventos culturais e artísticos, como o museu. Um dos fenómenos comunicativos aí circulantes é a literacia artística informal, processo diferente e às vezes oposto à educação formal ministrada na escola. Para tal, em primeiro lugar, são definidos dois conceitos fundamentais nos Estudos de Comunicação da Arte, e necessários para este debate: a Comunicação Pública da Arte (Public Communication of Art-P(A) e a literacia artística. Em segundo lugar, questões relativas à comunicação de arte são formuladas: a definição de políticas culturais que permitem a inclusão cultural de diversos segmentos de públicos de arte; o papel dos dispositivos digitais por forma a aprofundar a compreensão do património cultural; as estratégias de comunicação e de gestão mais adequadas para melhorar a literacia dos públicos; o processo de receção realizado pelas audiências culturais em torno de ideias e conceitos sobre a arte, partilhados em eventos artísticos. Em terceiro lugar, tais questões são situadas no seio das principais posturas teóricas e autores da área da Comunicação da Arte. Em seguida, são expostos alguns breves conselhos práticos e recomendações sobre como desenvolver uma investigação acerca da comunicação nos mundos da arte, em duas 
partes: a primeira sugere algumas hipóteses correspondentes às questões formuladas anteriormente. A segunda parte estabelece uma agenda sucinta e prática para realizar uma pesquisa sobre este assunto. Alguns dispositivos sociológicos emergentes, produzidos para fortalecer o impacto social e cultural da comunicação da arte, são igualmente apresentados. Finalmente, modos e metas específicos desse impacto são discutidas.

\author{
Palavras-chave \\ Comunicação pública da arte; Estudos de Comunicação da Arte; literacia \\ artística; metodologia sociológica intermédia; recepção da arte
}

\title{
INTRODUCTION
}

This text intends to reflect on art communication, both considering (a) its social relevance as an innovative and sustainable process, and (b) outlining its sociological meaning, in particular how to interpret it through an Open Research. To illustrate such aims, the article focus on urban cultural spaces, as the museum, where art events and the correspondent literacies are activated by art professionals and by publics, among other core cultural actors.

In this perspective, Public communication of Art is a recent concept developed within art communication studies, mainly at a project funded by Foundation for Science and Technology - FCT (Ref. PTDC/CCI/68595/2006) and undertaken from 2007 until 2011 under the author's coordination and undertaken from 2007 until 2011 (Andrade, 2016). Essentially, public communication of art means the process that articulates art production by artists and art reception by art publics, through the translation of a specialist artistic knowledge into the language of common knowledge, understandable by different segments of art publics. Such process occurs within art worlds (Becker, 2008), which are essentially networks of qualified people within specific cultural areas, in order to produce and disseminate art works. For instance, artists, art curators, museum directors, art teachers, art critics, collectors, auctioneers and other professional cultural staff, operate such mediation at art museum or at art galleries networks.

As for literacy, a former project, also funded by FCT (Ref. POCTI/SOC/35279/2000. and coordinated by the author from 2000 until 2005, was one of the first studies to enlarge the social and semantic meaning of this concept, through a research on scientifictechnological literacy inside science museums (Andrade, 2010a). In what regards art literacy, this is a strategy of both writing art (that is, creating art works by artists and presenting them publically by museum staff), and reading art (its appreciation and judgments by art publics). In particular, digital literacy is central for developing social/cultural inclusion for citizens and tourists, through emerging activities in cultural communication using digital new media. This debate aims to overcome a deficit in art communication studies literature in Portugal and dialog with other research perspectives within this field. 
Other earlier research conducted by the author on this text's main subject, art communication, is mentioned below, concerning cultural policies and heritage, public and private arts, museums social space and time, art inside cyberspace and cybertime, Art Social Ontologies and social relations mediated through art.

\section{SOME QUESTIONS ON ART COMMUNICATION}

Question 1. What cultural policies on art institutions governance may develop stimulating conditions for creative art communication and literacies, in order to encourage a stronger cultural inclusion through frequentation of art events, by multiple and diversified audiences. E.g., in the art museum, the cultural inclusion of both traditional visitors (families, schools, tourists) and still excluded publics (retired and disabled people, immigrants, refugees).

Question 2. Which cultural heritage / transcultural memory can be promoted via digital devices and archives, to consolidate publics' knowledge on culture and their cultural identity?

Question 3. What management / communication strategies were or can be implemented in art events to deepen audiences' art communication and literacy, and to foment stronger manifestations of opinion on art and cultural citizenship?

Question 4. How can we understand (ethically and aesthetically) the processes of cultural events' reception, and the apprehension of art concepts and methods using traditional and digital devices, by the above mentioned art publics profiles, through their actual, in-presence, visits, or via the digital social networks they frequent?

To answer such questions, art communication studies may analyze emerging social contexts of art events management, policies trends and cultural heritage forms such as digital art archives, and enhance digital methods applied in former studies. Research final results (journal articles, books, e- books/games), should be compared with previous findings, and diffused globally at scientific networks, exhibitions and training actions at museums, universities, cultural firms and art fairs.

Regarding methodology, researchers may use questionnaires, interviews, direct observation, and even new sociological methodologies such as games for teaching and research art and museology.

\section{Debates And authors on Art Communication Studies}

The state of the art regarding this problematics is here presented in articulation with the questions raised above.

To develop question 1, it is important to consider the literature on cultural policies for implementing art literacies at cultural events, and specifically public art policies. A collection of recent studies on public art (Andrade, Marques \& Barros, 2010) include analyses on urban policies and politics by Malcolm Miles (University of Plymouth) and Antoni Remesar (University of Barcelona), two of the more legitimated experts on public 
art within urban spaces. In a diachronic perspective, it is necessary to consider the history of museum discourse (Bennet, 1999) and of cultural policies (Sherman, 1999). Other approaches on this theme are the following: their relations with social inequalities, such as cultural inclusion policies (Sarraf, 2010); the dialectical dimension of cultural policies, found within "culture wars" (Bolton, 1992); the social vigilance inherent to some of such policies, translated by the concept "censorship culture" (Atkins, 2006); some pragmatic applications of cultural policies, e.g. museum governance (Malaro, 1994); frictions among that policies and socio-cultural differences, considered within the 'politics of identity' (Appiah, 2008); and the inclusion of cultural policies within international relations, in terms of development of a cultural diplomacy (Luke, 2012).

Question 2: Concerning cultural heritage and inter/transcultural memory for stimulating audiences knowledge and cultural identity, some major discussion subjects are these: public art heritage was deconstructed through critique of the archive and memory related to official and marginalized public and private arts (Andrade, 2009); the conditions and results of cultural heritage sustainability (Bouchier, 2012); "Memorylands" or instruments for European identity (MacDonald, 2013); heritage articulated with development, specially concerning peripheral non-Western countries (The World Bank, 2001); heritage as intercultural memory in a post-colonial world (Chopra, 2001); heritage as a cultural touristic target (Boniface, 1993); painful or "difficult heritage" such as the holocaust or Ground Zero (Logan, 2008)

Question 3: As regards communication management and methods within art events activated by professional staff and by communities of "cultural citizens", e.g. in the museum, in order to improve art literacy, opinion on art and cultural/digital citizenship, some central issues are the following ones: museum's public communication of art (Andrade, 2016), not yet enough reflected in Portugal; the museum profound diachronic transformations (Knell, 2007); museums within the global art world (Thornton, 2009); museum as a creative enterprise (Buskirk, 2012); museum marketing for gathering faithful audiences (Kotler, 208); museum branding within an economic and cultural crisis context (Wallace, 2006); education of museum staff for innovative careers (Burdick, 2008); the production of art "visitability" by cultural institutions (Dicks, 2003); the integration of publics opinions in decision making within the arts field (Wells, 2013); a pragmatic evaluation of museum activities (Diamond, 2009);

Question 4: As for art reception and opinion from cultural publics: it is crucial that museum managers could be open not just to traditional art literacy strategies, but to novel ones as well, such as storytelling (Dudley, Barnes, Binnie, Petrov \& Walklate, 2012). Beyond that, scientific and technological literacy at the museum can be activated by teachers and students (Andrade, 2010). Moreover, diverse visitors segments as families (Dierking, 2013), long life learners (Wilkening, 2009), tourists (Kotut, 2011) and immigrants (Allen, 2006), who may react differently to museum's cultural dispositifs, and even show distinct critical literacies when they use digital devices (Warnick, 2002). Other aspects contributing for this debate among art gatekeepers and publics are: safety within the use of digital literacies (Jacobson, 2012); multimodality literacies in our digital world 
(Rowsell, 2012); participatory culture and "edutainment", which means the articulation of education with entertainment (Aldrich, 2009). All these dimensions of art reception may be invested as pretexts for the enhancement of digital citizenship (Jenkins, Clinton, Purushotma, Robison \& Weigel, 2009).

\section{PleAding For CONCEPTUAL AND METHOdOLOgICAL inNOVATION}

Innovation is a transversal process, to be applied not just within economical and technological activities, but also inside culture and knowledge, and even be cultivated as “independent invention" (Leite \& Mota-Ribeiro, 2004). The previous research undertaken by the present text's author includes some major points on the following and related subjects, as possible innovative contributions to Art Communication Studies within the present networked and knowledge society. Let me give just some examples:

(a) The first systematic sociological reflection in Portugal on digital networks (1985), some years before the implementation of World Wide Web.

(b) Suggestion of a Sociology of Internet and the concept of cybertime (1996). Cybertime may be defined as the diachronic set of rhythms, compasses, cadences, pulses, beats or fluxes used by an internet user when he/she travels across cyberspace. Three main cybertime modes can be distinguished: firstly, a synchronous mode, visible at the use of chats, Skype and Hangouts conversations, etc.; secondly, an asynchronous mode, activated by web pages. And thirdly, a semi-synchronous mode is present at digital social networks, like Facebook, Instagram and Pintrest, but even more clearly within microblogging, as it happens in Twitter, where messages can be exchanged very quickly, trough re-tweeting of content indexed with hashtags.

(c) Some major concepts in museology, like "museability" (2000-10). This term means the articulation among economic, social, political and cultural contexts that condition musealization. And this last keyword signifies the strategies that art curators apply at exhibitions and at other knowledge and cultural events, in order to translate the expert knowledge of scientists and artists, into the common knowledge used by common citizens that visit the museum.

(d) New methodologies for Sociological Open Research, using an articulation of traditional and new media dispositifs (see details at the section that precedes the conclusion).

(e) The delimitation of an emerging paradigm of society, the Research Society.

In fact, we are not so much immersed in the information society, but rather within a networked knowledge society. The present knowledge turn is so profoundly diffused and reformulated, that we may define our contemporaneity as a Research Society. The first characteristic of this new social reality, is that expert knowledge is being converted, more and more, into open knowledge, often disseminated via top-down strategies, for instance through the implementation of open access inside academic repositories, virtual libraries and museums, etc.

However, some bottom-up strategies are emerging. Let me present an example that is a second attribute of research society: nowadays, common citizens, using 
computers, the internet, social networks and mobiles, are exchanging information news and open knowledge sometimes quicker than professional journalists, or even faster and with more accurate content than some academic researchers. Blogs and Wikipedia are two of the first models of this knowledge revolution. In fact, blog authors, who are not necessarily experts in a given area, daily, suggest new "tags", i.e. keywords to comment or evaluate content. Note that such words may become literally new concepts, through the hybridization of common and erudite meanings. A step further is done by Wikipedia participants, who may suggest, besides new concepts, new definitions and typologies on all themes debated within cyberspace and cybertime (Andrade, 2008).

\section{How Can we Research Art Communication?}

The questions raised above may be summarized in this way: how cultural policies and cultural heritage archives work as social frames for innovative art communication among cultural gatekeepers and cultural publics, and for more effective art reception and art literacy by diversified audiences, promoted through classical or via digital devices and archives?

For the clarification of this major problematics and implementation of the respective pertinent actions, here are some working hypotheses that try to answer, even partially, to each one of the previously enunciated questions:

Hypothesis 1. Transformations within global economy, communication, knowledge, art literacy and art events publics, specified above, should be more considered by lucid policy makers and art professional staff on art events governance, seeking in particular a more profound cultural inclusion of all citizens. In other words, it is useful that art researchers and cultural professionals suggest recommendations to other stakeholders, on how cultural policies may implement a better cultural heritage, archiving and memory, regarding art literacies operated at art events. This constitutes a necessary challenge and complementary alternative for education provided at traditional knowledge institutions, like schools and universities.

Hypothesis 2. New inter/transcultural memory/archives and cultural heritage are arising through the convergence of intermedia knowledge sources, perpetrated partly through digital instruments and mobile devices as mobile phones and digital pads. This process requires novel strategies for organization of knowledge, as "Memorylands" (MacDonald, 2013) or Art Social Ontologies, which are collections of art concepts articulated through social relations (Andrade, 2011b).

Hypothesis 3. Art literacies are gradually being hybridized with other literacies, e.g. scientific and technological literacies. Art events staff should develop his education and training on art and management literacies, designed specifically for innovative careers. Some of these strategies are corporation's creative marketing, museum and galleries branding campaigns, more intensive (but also critic) use of interactive digital devices.

Hypothesis 4. Classical and emerging art audiences are producing specific suggestions and critiques regarding the ethics and aesthetics of art worlds and art works, and 
that should be compared and merged with accounts produced by art gatekeepers such as policy makers and museum staff.

\section{AN OPEN RESEARCH AgendA FOR ART CoMmunicAtion}

For testing such hypotheses, an agenda for the next years may be planned considering these phases:

Year 1. Research planning: initially, this step includes the compilation of a bibliography / documentation dossier, in this case about innovative cultural policies, heritage, art events management, art publics, etc. However, besides that, tools for visualizing the research process may prove to be very useful, as concept maps. Moreover, prototypes of new methods and techniques for practical hypermedia products are already being used in education and research in social sciences and humanities, and tested at concrete cultural spaces, as the museum (please see the section that precedes the conclusion).

Year 2. Collection of empirical data: questions / hypothesis may be corroborated through questionnaires and interviews with art curators and their publics; and direct observation of art events spaces is undertaken, more and more, through videos.

Year 3: Interpretation of data includes the analysis of spaces and social scapes where art works are produced and disseminated; this may be done through the construction of Internet sites and via participation within social networks to present work in progress.

Year 4: Final Report writing and publication of final results, opinions and recommendations.

Year 5: Dissemination and discussion of the project within various cultural events and media or through the organization of conferences, seminars, workshops.

In a daily basis, this research data and respective analysis may be organized through several concrete databases:

- Bibliographic / documentary database containing digital bibliographic references and PDF documents in several media/hypermedia, produced by the most prominent authors and titles that are relevant to this subject. Selected quotations should be digitized into this database.

- Physical Library of books, review articles, paper documents and sources in hypermedia (CDs/DVDs, games, etc.).

In practical terms, the following devices will be useful:

(a) To formulate research questions and hypotheses;

(b) To develop the argumentation supporting the demonstration of that hypothesis;

(c) To write papers for presentation in congresses, conferences, seminars and journals with peer reviewing during the research.

- A statistical database including the main economical, social and cultural indicators for supporting the hermeneutics (i.e. a set of interpretations) of the discussed cultural and artistic processes. For example, user quantitative socio-cultural indicators can be analyzed (through factorial analysis, data mining, etc.) and interpreted for testifying or recommending different cultural policies in articulation with the art events participants' practices. 
- An interviews base containing interviewees' testimonies can be used as a pedestal for content and discourse analysis, and for partial or final report writings.

- A questionnaire database gathering the data obtained in the field, regarding a selected sampling of art events visitors and informants.

- An intermedia database including images, sounds and text collected from direct observation. This includes innovating behaviors and visual literacy actions produced by common agents and local communities at urban spaces and scapes and at public cyberspace. Video data collection is followed by the respective log analysis.

\section{STRATEGIES TO MEASURE ART COMMUNICATION'S SCIENTIFIC AND SOCIAL IMPACT}

The main outcomes of this kind of research may be understood as a heuristic strategy cultivating innovation, to be pursued through the following tactics:

(a) Theoretical/empirical sociological studies and respective journal articles, books and e-books on policies and heritage strategies concerning conflicting and cooperative literacies inherent to communication at art events.

(b) A social ontology of art events. Ontology, in the information society conceptualization and not within a philosophic connotation, means a collection of concepts articulated by relations (for more details, see the Glossary). In this case, it means a database and a knowledge base on projects themes and their relationships, including original concepts (e.g. "museability", mentioned above) and as well more normalized ones. Such concepts may also be associated through relations extracted from an "Alphabet of Interconceptual Relations" (Andrade, 2009), developed for the management of CMS's (content management systems). The aim is to enhance the conceptualization tools within Art Communication Studies. For example, the following notions and practical ideas suggested at the above mentioned project named Public Communication of Art: socio-semantic and meta-semantic indexes and conceptual abstracts for the organization of CMS content (Andrade 2011a, b).

(c) Hypermedia products for education/research in sociology, communication and arts. Some were implemented at the project Public Communication of Art, such as the first Portuguese Multitouch Questionnaire. Other action undertaken in this project is a Experimental Books Collection, that diffuses essays innovating in the content, form and structure of the medium "book", and is published by Caleidoscópio, Lisbon (Andrade, 2011b).

More educational tools are being developed at University of Minho, as an educational game named Read/Write Art. The game allows an art event visitor to use articulated literacies (reading/writing strategies) to communicate, by observing (reading) art works, and adding (writing) comments, through instruments, languages and terms associated with diverse literacies. For example, when a visitor 'reads', selects or writes scientific or artistic words, terms or concepts, he/she is applying, together or alternatively, scientific or artistic literacies. More score points will be given to a more intelligent use of a given literacy mode by a visitor. The social use and modes of communication of such literacies are analyzed through interviews at art events. 
(d) New Social Sciences and Humanities methods.

Besides the multitouch questionnaire above mentioned, refl-action may be understood as a method that articulates reflection and action in an open way. It uses some characteristics of Open Research, e.g. openly using Big Data's analysis procedures across Web 2.0 social networks, and in particular the interpretation methods subjacent to Big Knowledge's, within Web 3.0 social-semantic networks. For more details on these concepts, please consult the Glossary.

\section{Conclusion}

With the above proposed debate and related initiatives, it is possible to contribute, in the short, medium or long term, to the improvement of knowledge, culture and digital communication and literacies, within scientific strategies produced by academic communities, but also in dialogue with other stakeholders in civil society (citizens, corporations, spin offs, start ups, and in in consonance with the national and local cultural policies.

For example, theoretical and empirical findings may constitute, knowledge dispositifs on museology's epistemology/theory. In the above mentioned and other projects, an Interdimensional Networks Sociology approach was developed from 2000 until 2005. It used new kinds of social networks' analysis including actors in co-presence, and articulated with social dimensions (Andrade, 2010a). And a Semantic-Logical Sociology perspective was constructed (2007-2011), assumed as a posture closely associated, but critical, to Web 2.0 processes, through the reflection on art events activated through digital social networks, but also related to Web 3.0, that is, through the study of social semantic networks inherent e.g. to Wikipedia (Andrade, 2011).

Such outcomes' impact may be a contribution to the following pedagogical / research activities within global scientific communities world wide, which may apply such knowledge to solve society and economy issues, at different levels, such as the following ones:

- Global / local scientific community level: it is welcome a sustainable implementation of consistent research employment policy, for instance hiring students for working as grantees within research teams; and the encouragement of new teams at research centres, composed by national and international/intercultural high qualified PHD owners as members and consultants.

- Epistemological level: edification of an Open Research on art events and works, meaning a tolerant but critical mode and style of investigation e.g. on such subjects, an openness concerning theory, methodology, scientific teams and cultural citizenship debates.

- Theoretical level: innovation inside the problematics and themes for art events research; deconstruction/reconstruction of sociological theories on art events and their publics within scientific communities.

- Methodological level: development of new methodologies for sociological, hypermedia and social activities. 
- Socio-economic level: deeper articulation between research and education of citizens, through permanent training in new skills originated through new knowledge or methods, within Sociology, new media and arts; development of lifelong literacy, e-learning, etc. directed to broader research audiences, so that public understanding of arts and Social Sciences couldn't be assimilated any more only by scholars (teachers, students, researchers) but also by common citizens, inside social networks, knowledge institutions and communities; articulation among arts/social sciences and political/cultural citizenship through sharing of information/knowledge and via understanding common citizens as a sort of lay (non-expert) scientists/researchers.

In sum, Art Communication is more and more a promising arena to develop, within Sociology or other Social and Human Sciences. For example, Helena Pires (2005) conducted an interesting interview with Gunther Kress, where he clarifies point of view regarding Multimodal Social Semiotics, applied to visual modes and media.

We believe that Art Communication reflection and empirical studies may be undertaken, partly, through a more attention deployed by researchers and by other social stakeholders mentioned above, in what regards the profound transformations that are happening within our globalized public sphere. Two examples are interpretations of the artistic literacies deconstructed and reconstructed within public and informal cultural spaces such as the museum; or the process of mediation of social and cultural relations via the convergence and remediation of digital media. In fact, art communication today can't be understood without considering a serious debate on public communication of art.

Traduzido por Pedro Andrade

\section{BIBLIOGRAPHIC REFERENCES}

Aldrich, C. (2009). Learning online with games. San Francisco: Jossey Bass.

Allen, G. (2006). The role of the museum in creating multi-cultural identities. Lewiston: Edwin Mellen.

Andrade, P. (1985). Para uma sociologia da documentação: sensibilização à necessidade da sua construção, In Associação Portuguesa de Bibliotecários, Arquivistas e Documentalistas (Ed.), Actas do $1^{\circ}$ Congresso Nacional de Bibliotecários, Arquivistas e Documentalistas, 'A informação em tempo de mudança' (pp. 421450). Lisbon: BAD.

Andrade, P. (1996). Sociologia (interdimensional) da internet. In Actas do $3^{\circ}$ Congresso Português de Sociologia, Lisboa, 20- 24 Fevereiro. Associação Portuguesa de Sociologia [CD-ROM].

Andrade, P. (2007).O alfabeto de relações universais. Revista de Comunicação e Linguagens 'Mediação dos saberes', 38, 143-55.

Andrade, P. (2008). A sociedade da investigação e do jornalismo: boas práticas de cidadania participativa através da Internet móvel e do social bookmarking. In H. Sousa, S. Marinho \& R. P. Rocha (Eds.), Anuário Internacional de Comunicação Lusófona (pp. 307-312). Oporto: Campo das Letras.

Andrade, P. (2009). Arte pública e alteridades artísticas urbanas: os outros espaços de memória, escrita e arquivo. Revista de Comunicação e Linguagens 'Escrita, Memória, Arquivo', 40, 155-68. 
Andrade, P. (Ed.) (2010). Museus, públicos e literacia científico-tecnológica: redes de comunicação de significados no espaço interdimensional do museu. Lisboa: Edições Colibri.

Andrade, P. (2011a). Sociologia semântico-lógica da Web 2.0/3.0 na sociedade da investigação. Lisbon: Edições Caleidoscópio.

Andrade, P. (2011b). Public communication of art./Wars for peace/experimental books/Web3 novel. Retrieved from https://sites.google.com/site/compubartenglish/ https: //sites.google.com/site/peacewarsenglish; https: //sites.google.com/site/livrosexperimentaisenglish https: //sites.google.com/site/web3novelenglish/

Andrade, P. (Ed.) (2016). Comunicação pública da arte: o caso dos museus de arte locais e globais. Lisbon: Edições Caleidoscópio.

Andrade, P.; Marques, C. \& Barros, J. (Eds.) (2010). Arte pública e cidadania: novas leituras na cidade criativa. Lisbon: Edições Caleidoscópio.

Appiah, K. (2008). The politics of culture. Toronto: ROM.

Atkins, R. (Ed.) (2006). Censoring culture. New York: New Press.

Becker, H. (2008). Art worlds. Oakland: University of California Press.

Bennett, T. (1999). The birth of the museum. London: Routledge.

Bolton, R. (1992). Culture wars. New York: New Press.

Boniface, P. (1993). Heritage and tourism in 'the Global Village'. London: Routledge.

Bouchier, D. (2012). Cultural heritage and the challenge of sustainability. Walnut Creek: Left Coast Press.

Burdick, J. (2008). Creative careers in museums. New York: Allworth.

Buskirk, M. (2012). Creative enterprise: contemporary art between museum and marketplace. London: Continuum.

Chopra, R. (2011). Global media, culture, and identity. London: Routledge.

Diamond, J. (2009). Practical evaluation guide. Lanham: AltaMira.

Dicks, B. (2003). Culture on display: the production of contemporary visitability. London: Open University.

Dierking, L. (2013). Museums Q families. Walnut Creek: Left Coast Press.

Dudley, S.; Barnes, A.; Binnie, J.; Petrov, J. \& Walklate, J. (Eds.) (2012). Narrating objects, collecting stories. London: Routledge.

Jacobson, D. \& Idziorek, J. (2012). Computer security literacy. London: Chapman \& Hall.

Jenkins H.; Clinton, K.; Purushotma, R.; Robison, A. J. \& Weigel, M. (2009). Confronting the challenges of participatory culture. Cambridge, Mass.: MIT Press.

Knell, S. (2007). Museum revolution. London: Routledge.

Kotler, N. (2008). Museum marketing and strategy. San Francisco: Jossey Bass. 
Kotut, E. (2011). Cultural tourism and the museum concept. [s.l.]: Lap Lambert Acad.

Leite, C. \& Mota-Ribeiro, S. (2004). Produção, recepção e circulação do 'novo': um olhar sociológico sobre a invenção independente. Comunicação e Sociedade, 6, 211-234.

Logan, W. (Ed.) (2008). Places of pain and shame: dealing with 'difficult' heritage. London: Routledge.

Luke, C. (2012). US cultural diplomacy and archaeology: soft power, hard heritage. London: Routledge.

MacDonald, S. (2013). Memorylands: heritage and identity in Europe today. London: Routledge.

Malaro, M. (1994). Museum governance. Washington: Smithsonian.

Pires, H. (2005). A new grammar of visual design - Entrevista com Gunther Kress. Comunicação e Sociedade, $8,313-318$.

Rowsell, J. (2012). Working with multimodality: rethinking literacy in a digital age. London: Routledge.

Sarraf, V. (2010). Museum rehabilitation: cultural inclusion policies through accessibility. Saarbrücken: VDM Verlag Dr. Müller.

Sherman, D. (1989). Worthy monuments. Cambridge, Mass.: Harvard University.

The World Bank (2001). Cultural heritage and development. Washington: WB.

Thornton, S. (2009). Seven days in the art world. New York: Norton.

Wallace, M. (2006). Museum branding. Lanham: AltaMira.

Warnick, B. (2002). Critical literacy in a digital era: technology, rhetoric, and the public interest. London: Routledge.

Wells, M. (2013). Interpretive planning for museums: integrating visitor perspectives in decision making. Walnut Creek: Left Coast Press.

Wilkening, S. (2009). Life stages of the museum visitor. Arlington: Amer Assn of Museums.

\section{ART COMMUNiCATION GLOSSARY ${ }^{1}$}

Art Communication Studies: theory, methodology and empirical research on Art Communication that may originate public debates on epistemological, conceptual and procedural questions, emerging during scientific research or defined as legitimated problematics. For example, Public Communication of Art is a concept that summons areas of knowledge such as Sociology of Art, Communication and New Media, among others. These knowledge areas have been studying processes like the phenomenon of muse$\underline{u m s}$, in conjunction with the discussion on cultural policies, cultural heritage, cultural citizenship or public art.

Art publics: audiences who include specific socio-demographic characteristics and develop particular communication careers, during their visits to art sites and events, for

\footnotetext{
Associated concepts are underlined.
} 
instance when they relate art works and the museum space with their own experience of the city, work, family and school. Some main public segments are: families; students and teachers from an education institution; an isolated visitor or groups that aim to perform continuous training throughout life; the cultural tourist. However, other profiles, still marginalized, are to be included within art publics, such as retired people, disabled people, immigrants and refugees.

Art worlds: socio-cultural networks joining several actors who have specific qualifications to organize production, mediation and dissemination of art works. This networked process is operated, in particular, by several art "gatekeepers" (art experts) aiming to reach diverse art publics.

Art gatekeepers: specialists in art worlds and on art works, who are located in key places of art networks, such as artists, art events staff or museums and art gallery professionals (directors, owners, curators and managers in educational services), or teachers, critics, collectors, auctioneers, etc.. These "gatekeepers" select and regulate the temporal course of artistic activities and the spatial paths of art works, since their production state, during various mediations at art institutions, organizations and associations, until their presentation within the public space and fruition by the art publics.

Big Data: a huge flux of data streaming at cyberspace and cybertime, that requires innovative methods for processing and disseminating content, such as data mining and data visualization.

Big Knowledge: knowledge flux is overwhelming at cyberspace and cybertime, Innovative strategies are being used to understand it, such as knowledge curation, ontologies and refl-action.

Cultural citizenship: it may be understood as a social fusion of cultural policies and cultural politics.

Cultural Heritage: this is a collection of archives and memories relating to a people, nation, country or community. Material cultural heritage includes mainly physical works, in areas such as architecture, arts, literature. etc. Immaterial cultural heritage gathers non-physical works, e.g. oral memories, cultural, intercultural and transcultural events, traditions, etc.

Cultural inclusion: there is a cultural divide among social actors. Besides traditional visitors to art events (high and middle classes, tourists, etc.), who have means to participate in cultural events (time, money, education, etc.), excluded art publics still exist (e.g. retired and disabled people, immigrants, refugees). Cultural policies on art institutions governance and art gatekeepers should increase conditions to integrate those marginalized citizens, not just through mere access to frequentation of art events, but stimulating their motivations and critical predisposition to participate.

Cultural policies: these are strategies developed by the state and by cultural institutions, in order to promote: cultural diplomacy; cultural governance by several social stakeholders; art literacies; cultural inclusion; public art; citizens identities and differences.

Cultural politics: this idea means the active, critical and political daily participation of citizens within democratic cultural life. 
Cybertime: it may be defined as the diachronic set of rhythms, compasses, cadences, pulses, beats or fluxes used by internet users when they travel across cyberspace.

Informal Art training: it is an artistic learning not observing rules, schedules, programs, tests, which is very common within social and cultural places of entertainment or information, such as the museum or cyberspace / cybertime.

Hybrid methods / hybrimedia: mixing, melting or hybridization of several scientific or artistic methods and media, for example those characteristic of the following knowledge modes: Social Sciences (questionnaire), new technologies (interactive digital devices made in hypermedia) and the arts (performance).

Knowledge curation: a process to transfer and share information and knowledge over cyberspace, cybertime, Web 2.0 social networks and in particular Web 3.0 socialsemantic networks. It operates by selecting, interpreting, assessing and disseminating content and corresponding public opinions, sometimes using Hybrid methods / hybrimedia.

Lay-scientist: an ordinary scientist or sociologist is a social actor or citizen who thinks and acts, actively and daily on the real and on society, producing concepts and their relationships, although differently from academic "experts", for example professional sociologists in Social Sciences.

Literacies: these are ways of reading and writing within a given mode of knowledge, such as natural language, everyday life, science, art and technology. Urban space articulates communication strategies where people trigger different literacies, e.g. formal literacies at school or informal literacies at leisure and information localities, like art events and the Internet.

Museability: social process that includes contextual, economic, socio-cultural and political conditions of musealization, within a given society.

Musealization: museum methods, actions and events involving presentation strategies forged by professionals belonging to that institution, that translate scientific, technological and artistic works and knowledge, into the common knowledge detained by audiences of non-specialists.

Museology: Specialized knowledge about the museum. "New museology" is one of its latest versions, based on the ideas of "eco-museum" and "art center", among others.

Museum: according to ICOM (International Council of Museums), museums are permanent institutions, conveying non-profit services to society development and open to the public. The museum also performs research on material evidence concerning man and his environment, acquires these sources, saves them, communicates them and in particular exposes them aiming their study, learning and enjoyment.

Museum types: the main ones are: the art museum; the museum of human sciences (historical, archaeological, anthropological museums, etc.); the museum of natural sciences; the museum of science and techniques; the eco-museum; and, more recently, the virtual museum.

Ontology: Its recent meanings should not be confused with the traditional philosophical connotation of "Ontology" understood as a reflection on the Being. Nowadays, 
ontologies are widely used in Computer Sciences and, more recently, within Social Sciences and Humanities. In this novel meanings, an ontology may be defined as a set of concepts and respective semantic and logical relations within a given knowledge mode. This deconstructed and reconstructed knowledge tool allows unprecedented hermeneutic/interpretation strategies concerning our economic, political, cultural and daily lives.

Open Research: type of research partly inspired on Umberto Eco Opera Aperta and on defense of free software and programming code modifiable, such as Open Source. It is characterized by at least 3 modes of "opening": 1. Teams including researchers within transdisciplinary and transcultural areas; 2. Tolerance of content and ideas coming not just from academics and other experts, but also from ordinary people, who can be understood as a sort of lay scientists. 3. Versatility regarding both classical and experimental methodologies, e.g. "refl-action".

Public Art: Artistic manifestation produced, exposed, perceived, judged and practiced at the public sphere, such as public urban sites (streets, squares, etc.), mass media, cyberspace / cybertime.

Public Communication of Art: socio-cultural process that involves the production, distribution, consumption and understanding concerning the various modes of artistic information and knowledge, within public or semi-public contexts, such as the museum, the art gallery or cyberspace / cybertime.

Public cyberspace: public space, constructed and reconstructed within the internet, by cultural citizens, among other social actors.

Refl-action. Sociological method that articulates reflection and action in a open way within Open Research, mainly at cyberspace and cybertime. Two examples are the open exchange of Big Data through Web 2.o social networks (e.g. actions among friends); and the permutation of Big Knowledge via Web 3.0 social-semantic networks (e.g. explainations of knowledge meanings).

Research Society: in contemporaneity, common citizens may search and openresearch information and knowledge, using global tools and devices such as Google or mobile phones, within multiple social scenes, including physical or virtual museum spaces. In so doing, they may construct concepts and definitions like at Wikipedia, and in some way compete with professional scientists and artists, regarding production and dissemination of not just information, but also knowledge.

Social semantic site: this kind of website is closely associated with Web 3.o. It explicitly presents an explanatory paradigm or sections regarding its own semantic content (ideas, concepts, etc.) and their logical relationships (connections between the ideas within the site or links among site pages and external internet locations).

Virtual museum/galleries: territory located in cyberspace and cybertime where users may develop, among other things, different and novel digital cultures, digital social networks, social games and new cyber literacies.

Visitor artistic literacy: Museum/art gallery visitor competence and performance in relation to artistic knowledge transferred and shared at these cultural localities. It depends on visitors level of education and cultural capital, but also on the exhibited 
art works' types, on exhibit presentation strategy and on the art understanding process convoked.

Web 2.0 (or Social Web or reading / writing Internet): type of digital social network that allows an active stance by the user: in addition to reading the information, he can write content such as articles (posts) or comments in a blog, and share personal and professional information across digital social networks, such as Facebook, Twitter or Youtube.

Web 3.0 or Semantic Web: digital social networking paradigm that is based, among other discursive devices, in social-semantic sites. Exs: Freebase, Public Communication of Art.

\section{BiOgRAPHICAL NOTE}

Pedro Andrade is a sociologist, researcher and professor at University of Minho. Phd in Sociology of Culture at FCSH, New Univ. of Lisbon (2002). He also taught at the University of Coimbra - Faculty of Economy and at University of Lisbon - Faculty of Fine Arts, in the areas of Sociology of Culture, Communication, Sociological Methods and Digital Humanities. Author of books and articles on art and science museums, communications and literacies, digital social networks (Web 2.0/Web 3.0), methodologies and hypermedia. Coordinator of several research projects and teams e.g. Scientific-Technological Literacy and Public Opinion: the case of science museums; Public Communication of Arts: the case of local/global art museums, both funded by Foundation for Science and Technology,

E-mail: pjoandrade@gmail.com

Rua D. Luís de Noronha, 26 1D, Lisboa, 1050-072, Portugal

* Submitted: 15-10-2016

* Accepted: 22-01-2017 